\title{
PD-1 Expression by Lymph Node and Intratumoral Regulatory T Cells Is Associated with Lymph Node Metastasis in Pancreatic Cancer
}

\author{
Adrian M. Seifert ${ }^{1,2, *,+}+{ }^{\circ}$, Annabel Eymer ${ }^{3,+}{ }^{,}$Max Heiduk ${ }^{1,4}$, Rebekka Wehner ${ }^{3,5}$, \\ Antje Tunger ${ }^{3,5}$, Janusz von Renesse ${ }^{1}$, Rahel Decker ${ }^{1}$, Daniela E. Aust 6,7, Thilo Welsch 1,2, \\ Christoph Reissfelder ${ }^{8}\left(\mathbb{D}\right.$, Jürgen Weitz ${ }^{1,2}$, Marc Schmitz ${ }^{2,3,5}$ and Lena Seifert ${ }^{1,2}$ (D) \\ 1 Department of Visceral, Thoracic and Vascular Surgery, Medical Faculty, University Hospital Carl \\ Gustav Carus, TU Dresden, 01307 Dresden, Germany \\ 2 German Cancer Consortium (DKTK), Partner Site Dresden, German Cancer Research Center (DKFZ), \\ 69120 Heidelberg, Germany \\ 3 Institute of Immunology, Medical Faculty Carl Gustav Carus, TU Dresden, 01307 Dresden, Germany \\ 4 National Center for Tumor Diseases (NCT), Partner Site Dresden, German Cancer Research Center (DKFZ), \\ 69120 Heidelberg, Germany \\ 5 National Center for Tumor Diseases (NCT), University Hospital Carl Gustav Carus, TU Dresden, \\ 01307 Dresden, Germany \\ 6 Department of Pathology, University Hospital Carl Gustav Carus, Medical Faculty, University of Dresden, \\ 01307 Dresden, Germany \\ 7 NCT Biobank Dresden, University Hospital Carl Gustav Carus, Technische Universität Dresden, \\ 01307 Dresden, Germany \\ 8 Department of Surgery, Universitätsmedizin Mannheim, Medical Faculty Mannheim, Heidelberg University, \\ 68167 Mannheim, Germany \\ * Correspondence: adrian.seifert@ukdd.de \\ + These authors contributed to this work equally.
}

Received: 18 August 2020; Accepted: 21 September 2020; Published: 24 September 2020

Simple Summary: Pancreatic cancer is a devastating disease and among the most immune-resistant tumor types. Single-agent immunotherapy has not demonstrated clinical benefits in pancreatic cancer patients, and combinational therapies targeting multiple mechanisms of immunosuppression are likely needed. T cell activation in lymph nodes is required for the efficacy of immunotherapy. Here, we phenotypically and functionally analyze T cells from tumor-draining lymph nodes, blood and tumors from patients with pancreatic cancer to decipher unknown immunosuppressive mechanisms and to identify potential immunotherapeutic targets.

Abstract: Pancreatic ductal adenocarcinoma (PDAC) is characterized by a mostly immunosuppressive
microenvironment. Tumor-draining lymph nodes (TDLN) are a major site for priming of tumor-reactive
$\mathrm{T}$ cells and also tumor metastasis. However, the phenotype and function of T cells in TDLNs
from PDAC patients is unknown. In this study, lymph nodes from the pancreatic head (PH),
the hepatoduodenal ligament (HDL) and the interaortocaval (IAC) region were obtained from
25 patients with adenocarcinoma of the pancreatic head. Additionally, tumors and matched blood were
analyzed from $16 \mathrm{PDAC}$ patients. Using multicolor flow cytometry, we performed a comprehensive
analysis of T cells. CD $4^{+} \mathrm{T}$ cells were the predominant T cell subset in PDAC-draining lymph nodes.
Overall, lymph node CD4 ${ }^{+}$and CD ${ }^{+} \mathrm{T}$ cells had a similar degree of activation, as measured by CD69,
inducible T cell co-stimulator (ICOS) and CD137 (4-1BB) expression and interferon- $\gamma$ (IFN $\gamma$ ) secretion.
Expression of the inhibitory receptor programmed death 1 (PD-1) by lymph node and tumor-infiltrating
regulatory T cells (Tregs) correlated with lymph node metastasis. Collectively, Treg cells and PD-1
are two relevant components of the immunosuppressive network in PDAC-draining lymph nodes 
and may be particularly attractive targets for combinatorial immunotherapeutic strategies in selected patients with node-positive PDAC.

Keywords: pancreatic cancer; tumor-draining lymph nodes; T cells; Treg cells; PD-1

\section{Introduction}

Pancreatic ductal adenocarcinoma (PDAC) is a devastating disease with fewer than $9 \%$ of patients surviving five years [1]. Lymph node (LN) metastases occur in approximately two-thirds of patients with resectable PDAC and are associated with poor prognosis [2,3]. In multiple solid tumors, including kidney, bladder and lung cancer, as well as melanoma, immunotherapeutic strategies substantially improved the overall survival. So far, the use of a single-agent immune checkpoint blockade has not demonstrated clinical benefits, however a very limited number of PDAC patients has been enrolled in these studies [4-6]. Notably, T cell activation in regional lymph nodes is required for the efficacy of inhibitory receptor blockade [7].

There is relevant data suggesting a heterogeneity with regard to the immunogenicity of PDAC [8]. $\mathrm{T}$ cells are the major immune cell type infiltrating PDAC, and the majority of resectable PDAC samples display intermediate to high levels of $\mathrm{T}$ cell infiltration [9-11]. Among these, $\mathrm{CD} 4^{+} \mathrm{T}$ cells, and especially conventional $\mathrm{CD} 4^{+} \mathrm{T}$ cells (Tconv), are the predominant $\mathrm{T}$ cell subset [12]. Further, spatial distribution of cytotoxic $\mathrm{CD} 8^{+} \mathrm{T}$ cells in proximity to tumor cells correlates with improved overall survival in pancreatic cancer [13]. An increased frequency of tumor-infiltrating regulatory T cells (Tregs) is associated with poor prognosis and Treg density further correlates with lymph node metastasis in PDAC [14-16].

The programmed death 1 (PD-1) and programmed death ligand 1 (PD-L1) axis has become a central target of immunotherapeutic approaches. PD-1 is an inhibitory receptor that is upregulated after T-cell activation and remains elevated with antigen persistence. Ligation of PD-1, through its ligands PD-L1 (B7-H1, CD274) and PD-L2 (B7-DC, CD273), delimits immunogenic responses. PD-L1 is expressed on immune and tumor cells and is associated with worse outcomes in PDAC $[17,18]$.

The state of $\mathrm{T}$ cell activation and exhaustion in tumor-draining lymph nodes (TDLNs) in human PDAC is unknown. In this study, we analyzed freshly isolated immune cells from several lymph nodes, blood and tumor specimens of PDAC patients.

\section{Results}

\section{1. $C D 4^{+} T$ Cells Are the Predominant $T$ Cell Subset in PDAC-Draining Lymph Nodes}

To determine the composition of $\mathrm{T}$ cell subsets in lymph nodes from PDAC patients, we performed flow cytometry on lymph nodes from three different locations, namely the interaortocaval (IAC), hepatoduodenal ligament (HDL) and pancreatic head (PH) lymph node region. All lymph nodes were freshly obtained and analyzed from a total of 25 PDAC patients undergoing surgery at our institution (Table S1). Representative dot plots for T cell gating are shown (Figure 1A).

The percentages of $\mathrm{CD}^{+} \mathrm{T}$ cells among leukocytes was similar between lymph node regions (Figure 1B). Overall, $\mathrm{CD}^{+}$Tconv cells were the predominant $\mathrm{T}$ cell population in lymph nodes (Figure 1C). Further, the $\mathrm{CD} 4^{+}$Tconv to Treg as well as the $\mathrm{CD} 8^{+} \mathrm{T}$ cell to Treg ratio was similar between lymph node locations (Figure 1D,E). These data suggest that the frequency of $\mathrm{T}$ cell subsets is unrelated to the distance of lymph nodes from the primary tumor. 
A
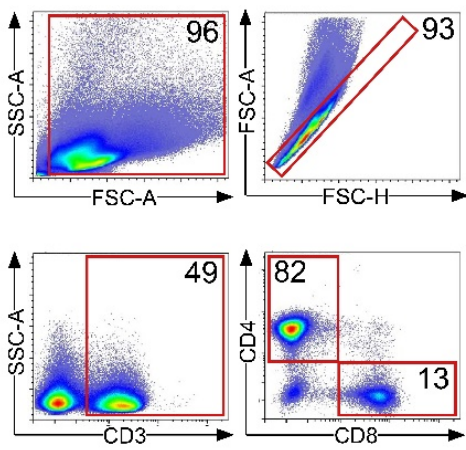

C

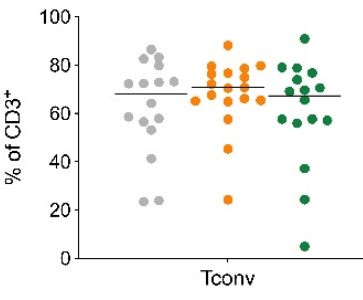

D

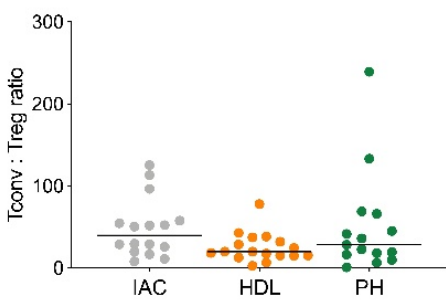
gated on $\mathrm{CD}^{+}$
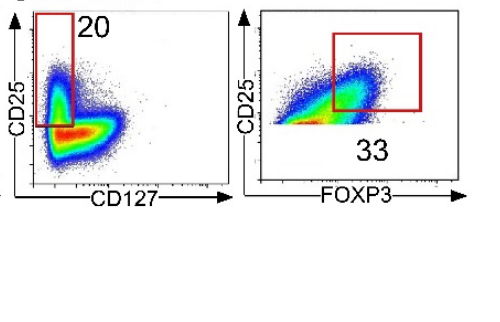

IAC

- HDL

- $\mathrm{PH}$

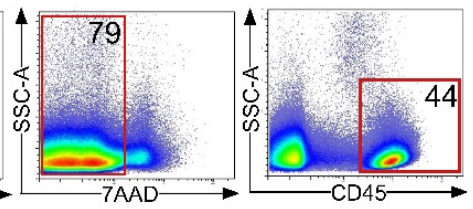

Figure 1. $\mathrm{CD}^{+} \mathrm{T}$ cells are the predominant $\mathrm{T}$ cell subset in pancreatic ductal adenocarcinoma (PDAC)-draining lymph nodes. (A) Representative flow cytometric gating strategy for the identification of T cells. Number indicates percentage of population per gate. SSC, side scatter; FSC, forward scatter. (B) Quantification of $\mathrm{CD}^{+} \mathrm{T}$ cells among all leucocytes $\left(\mathrm{CD} 45^{+}\right)$. (C) $\mathrm{CD} 4^{+}$Tconv cells (Tconv; $\mathrm{CD}^{+} \mathrm{CD}^{+}{ }^{+}$not Treg'), regulatory T cells (Treg; $\mathrm{CD}^{+} \mathrm{CD}^{+}{ }^{+} \mathrm{CD} 8^{-} \mathrm{CD} 25^{+} \mathrm{CD} 127^{-} \mathrm{FOXP} 3^{+}$) and $\mathrm{CD}^{+} \mathrm{T}$ cells $\left(\mathrm{CD}^{+} ; \mathrm{CD}^{+} \mathrm{CD}^{-} \mathrm{CD} 8^{+}\right)$as a percentage of $\mathrm{CD}^{+} \mathrm{T}$ cells in lymph nodes of the indicated location from patients with PDAC. (D) Ratio of CD4 ${ }^{+}$Tconv to Treg and (E) CD8 ${ }^{+} \mathrm{T}$ cells to Treg in lymph nodes. IAC, interaortocaval: lymph node around the abdominal aorta; HDL, hepatoduodenal ligament: lymph node along the hepatic artery and bile duct; $\mathrm{PH}$, pancreatic head: lymph node from the posterior aspect of the pancreatic head. Each point represents data from one patient. Data, median. One-way ANOVA.

\subsection{Central and Transitionally Memory $T$ Cells Constitute the Predominant $T$ Cell Differentiation Stages in PDAC-Draining Lymph Nodes}

Next, we analyzed the differentiation stages of T cells in PDAC-draining lymph nodes. Following antigenic stimulation, naive $\mathrm{T}$ cells generate multiple subsets of memory $\mathrm{T}$ cells with different phenotypic and functional properties [19]. The expression of CD45RA, C-C chemokine receptor 7 (CCR7), CD28 and CD95 was determined by flow cytometry (Figure 2A,B).

Overall, central memory $\mathrm{CD} 4^{+} \mathrm{T}$ cells (Figure $2 \mathrm{~A}$ ) and transitionally memory $\mathrm{CD} 8^{+} \mathrm{T}$ cells (Figure 2B) were the predominant $\mathrm{T}$ cell subsets in PDAC-draining lymph nodes. Notably, naive $\mathrm{T}$ cells also represented a significant subgroup in $\mathrm{CD}^{+}$and $\mathrm{CD} 8^{+} \mathrm{T}$ cells $(27 \%$ and $19.8 \%$, respectively). The distribution of memory $\mathrm{T}$ cells within the $\mathrm{CD} 4^{+}$and $\mathrm{CD}^{+} \mathrm{T}$ cell subset was similar between lymph node regions. 
A
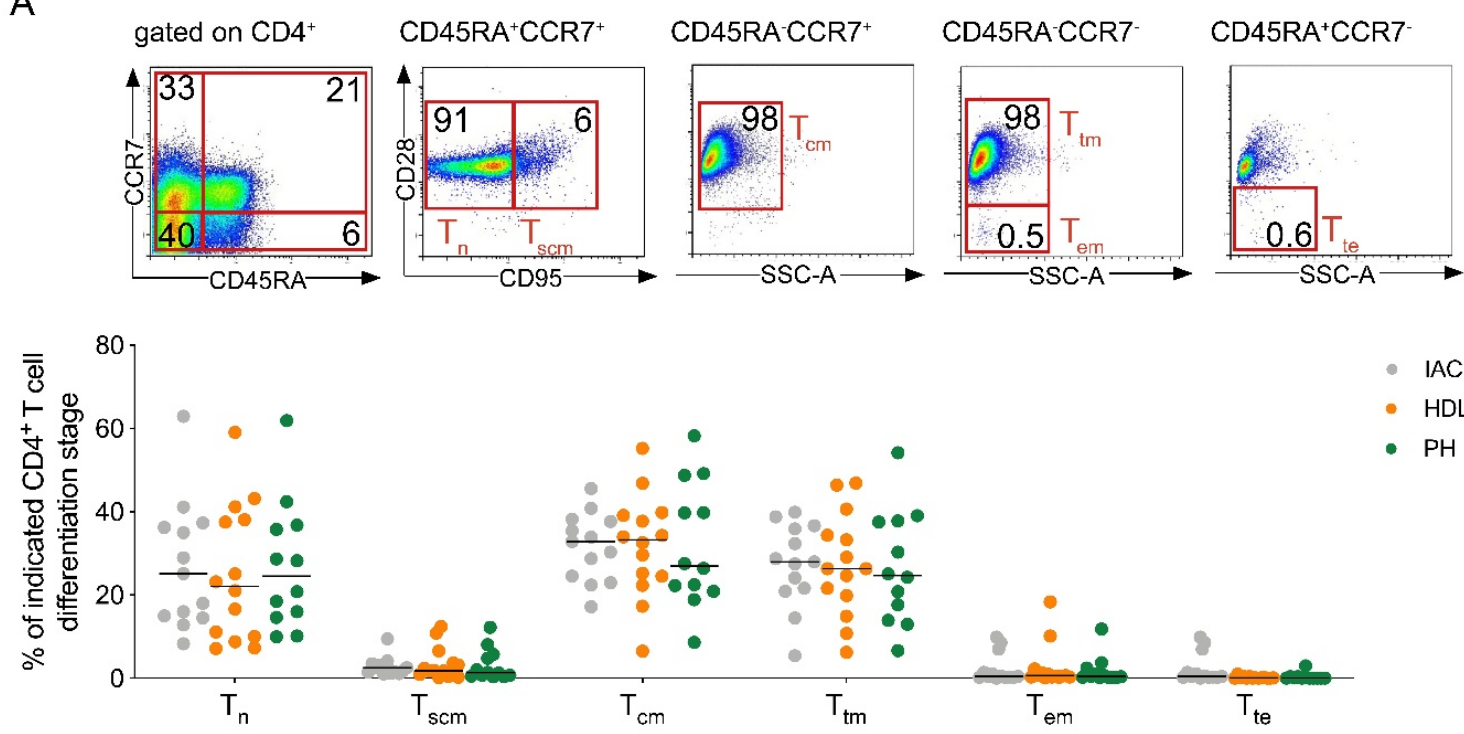

B
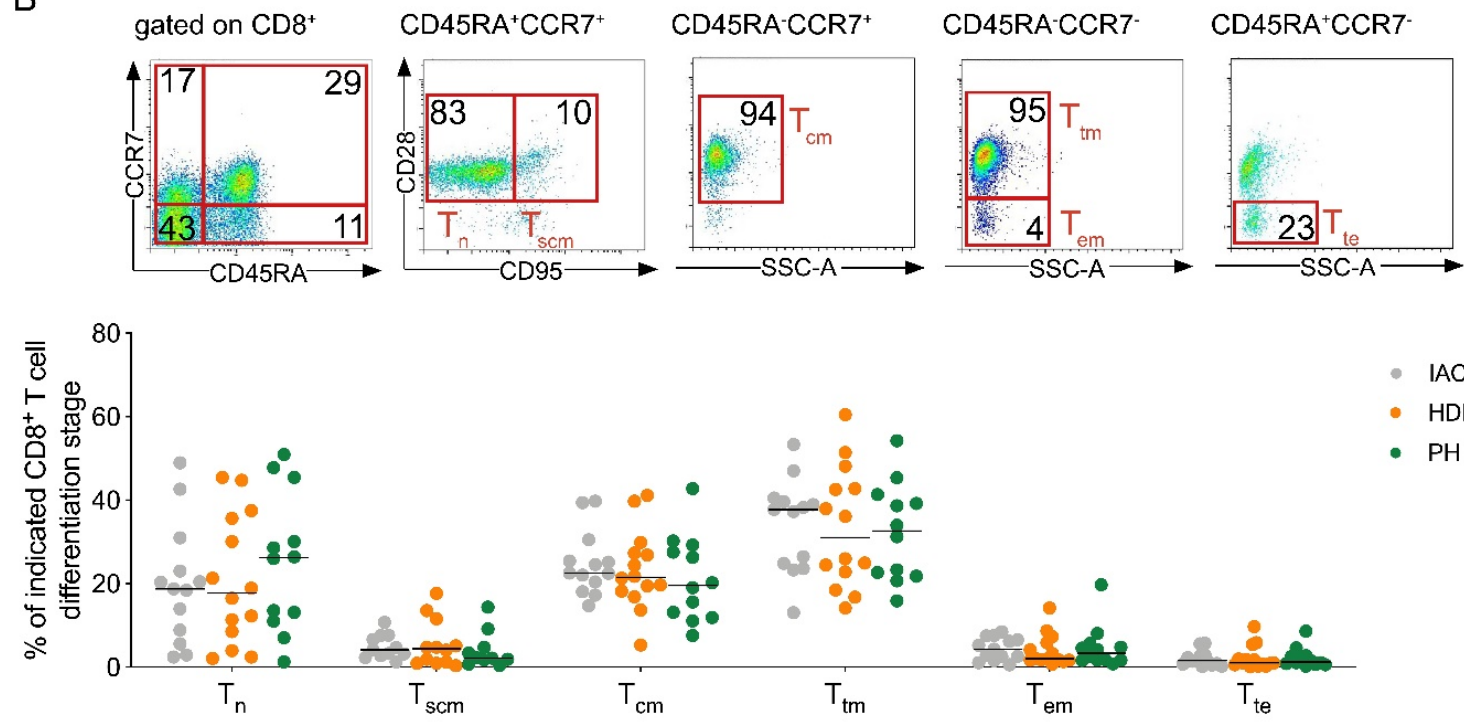

Figure 2. Central and transitionally memory $\mathrm{T}$ cells constitute the predominant $\mathrm{T}$ cell differentiation stages in PDAC-draining lymph nodes. (A) Representative flow plots (top) and frequency (below) of T cell differentiation stage in lymph nodes of the indicated location for $\mathrm{CD} 4^{+}$and $(\mathrm{B}) \mathrm{CD} 8^{+} \mathrm{T}$ cells. Tn, naïve $\left.\left(\mathrm{CD} 45 \mathrm{RA}^{+} \mathrm{CCR7}^{+} \mathrm{CD} 28^{+} \mathrm{CD}^{-}\right)^{-}\right)$; $\mathrm{Tscm}$, stem cell memory $\left(\mathrm{CD} 45 \mathrm{RA}^{+} \mathrm{CCR} 7^{+} \mathrm{CD} 28^{+} \mathrm{CD}^{+} 5^{+}\right)$; $\mathrm{Tcm}$, central memory (CD45RA $\left.{ }^{-} \mathrm{CCR} 7^{+} \mathrm{CD} 28^{+}\right)$; Ttm, transitionally memory $\left(\mathrm{CD} 45 \mathrm{RA}^{-} \mathrm{CCR} 7^{-} \mathrm{CD} 28^{+}\right)$; $\mathrm{Tem}$, effector memory (CD45RA $\left.{ }^{-} \mathrm{CCR}^{-} \mathrm{CD}^{-} 8^{-}\right)$; Tte, terminal effector $\left(\mathrm{CD}^{2} 5 \mathrm{RA}^{+} \mathrm{CCR7}{ }^{-} \mathrm{CD} 28^{-}\right)$. IAC, interaortocaval; HDL, hepatoduodenal ligament; $\mathrm{PH}$, pancreatic head. Each point represents data from one patient. Data, median. One-way ANOVA.

2.3. Lymph Node $\mathrm{CD} 4^{+}$and $\mathrm{CD} 8^{+} \mathrm{T}$ Cells Display a Similar Degree of Activation Independent of Distance from the Tumor

To determine differences in $\mathrm{T}$ cell activation in lymph node $\mathrm{CD} 4^{+}$and $\mathrm{CD} 8^{+} \mathrm{T}$ cells from PDAC patients, we stained for the activation markers CD69, inducible T cell co-stimulator (ICOS) and CD137 (4-1BB). Approximately $40 \%$ of $\mathrm{CD}^{+}$and CD8 ${ }^{+} \mathrm{T}$ cells expressed CD69 (Figure $3 \mathrm{~A}$ ).

$\mathrm{CD}^{+} \mathrm{T}$ cells showed higher levels of ICOS $(18.8 \%)$ compared to CD8 ${ }^{+} \mathrm{T}$ cells $(8.8 \%$, Figure $3 \mathrm{~A})$. The expression of $\mathrm{CD} 137$ was generally low on $\mathrm{CD}^{+}(3.6 \%)$ and $\mathrm{CD} 8^{+} \mathrm{T}$ cells $(2.8 \%$, Figure $3 \mathrm{~A})$. We next analyzed CD107a expression, a surrogate marker for cytotoxic $\mathrm{T}$ cell degranulation, and interferon- $\gamma$ 
(IFN $\gamma$ ) secretion (Figure 3B). CD8 ${ }^{+} \mathrm{T}$ cells showed higher IFN $\gamma$ secretion $(24 \%)$ compared to CD4 ${ }^{+} \mathrm{T}$ cells (6.3\%), but no difference in CD107a expression (22.6 and 31\%, respectively, Figure 3B). Collectively, the degree of $\mathrm{T}$ cell activation was similar in lymph nodes from different regions and unrelated to distance from the primary tumor.

A
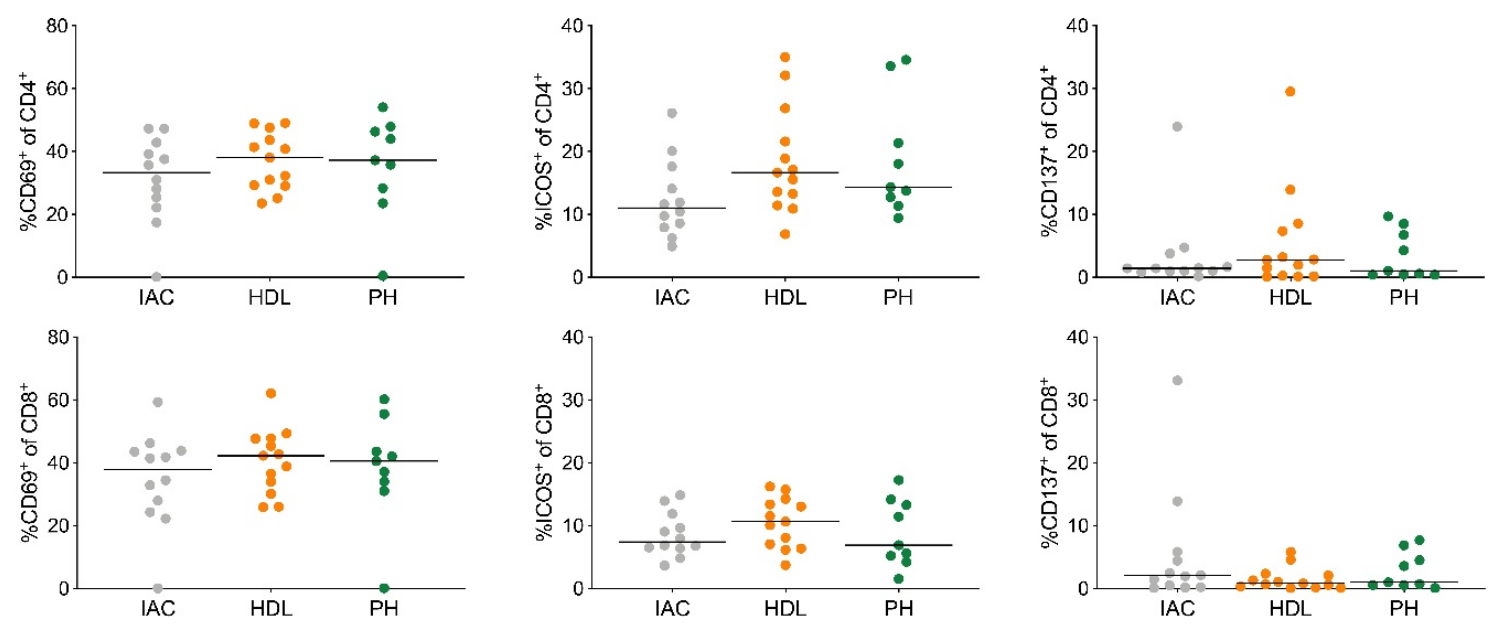

B
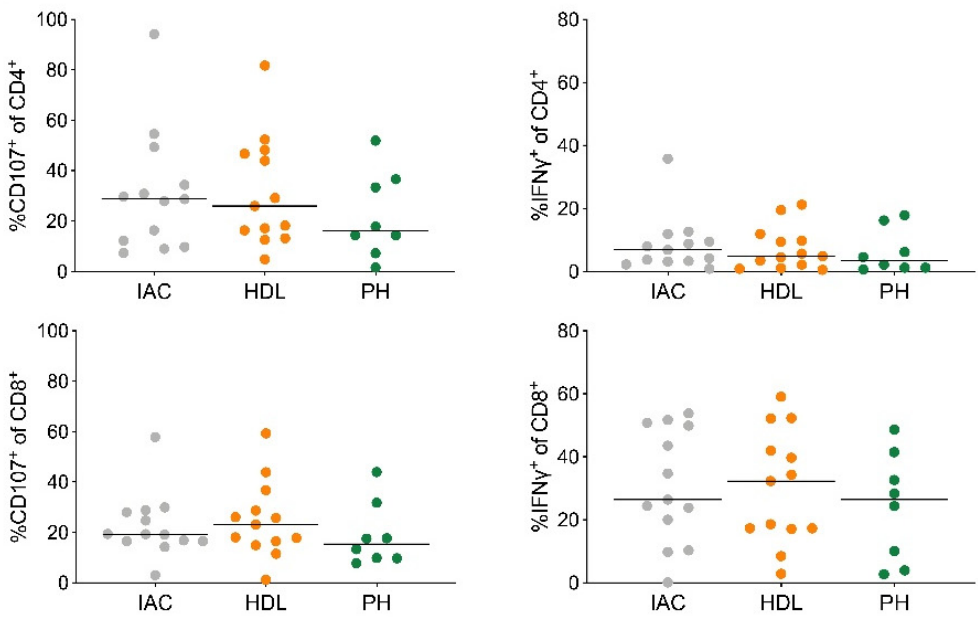

Figure 3. Lymph node $\mathrm{CD} 4^{+}$and $\mathrm{CD}^{+} \mathrm{T}$ cells display a similar degree of activation independent of distance from the tumor. (A) Quantification of the expression of the activation markers CD69 (left), ICOS (middle) and CD137 (right) on CD4 ${ }^{+}$(top) and CD8 ${ }^{+} \mathrm{T}$ cells (bottom). (B) Quantification of CD107a (left) expression and IFN $\gamma$ (right) secretion by stimulated CD4 ${ }^{+}$(top) and CD8 ${ }^{+} \mathrm{T}$ cells (bottom). IAC, interaortocaval; HDL, hepatoduodenal ligament; $\mathrm{PH}$, pancreatic head. Each point represents data from one patient. Data, median. One-way ANOVA.

\subsection{Treg Cells in PDAC-Draining Lymph Nodes Express PD-1 and PD-L1}

Antigen-specific and exhausted T cells typically express inhibitory receptors, including lymphocyte activation gene 3 (LAG-3), T cell immunoglobulin and mucin-domain containing-3 (TIM-3), cytotoxic T-lymphocyte-associated protein 4 (CTLA-4) and PD-1 [20,21]. Therefore, we analyzed the expression of these inhibitory receptors and also PD-L1 on lymph node T cells. CD4 ${ }^{+}$and $\mathrm{CD}^{+} \mathrm{T}$ cells both displayed very low LAG-3 expression (1.6\% and 3.8\%, respectively; Figure $4 \mathrm{~A})$.

However, approximately $20 \%$ of $\mathrm{CD}^{+}$and $\mathrm{CD}^{+} \mathrm{T}$ cells expressed TIM-3 (Figure 4B). Treg cells showed higher CTLA-4 expression (26.3\%) compared to CD4 ${ }^{+}$Tconv $(11.5 \%)$ and CD8 ${ }^{+} \mathrm{T}$ cells (10.2\%; Figure 4C). Notably, CD4 ${ }^{+}$Tconv, Treg and CD8 ${ }^{+}$T cells highly expressed PD-1 $(25.9 \%, 29.6 \%$ 
and 37.6\%, respectively; Figure 4D). PD-L1 was mostly expressed by Treg cells (53.6\%; Figure 4E). Especially, Treg cells from the pancreatic head lymph node displayed high PD-L1 expression. These data suggest that the PD-1/PD-L1 axis contributes to the immunosuppressive network in PDAC-draining lymph nodes.

A

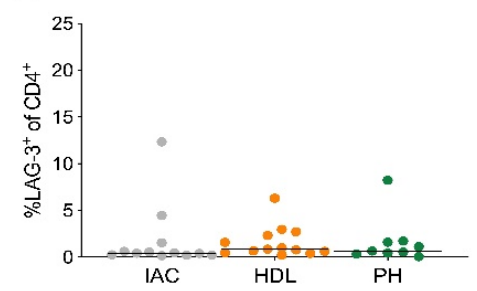

B

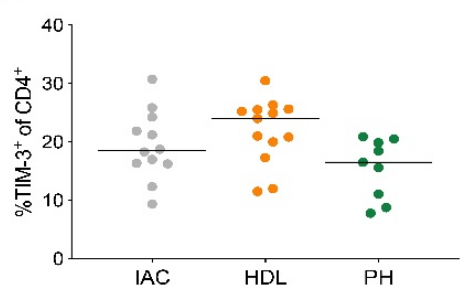

C

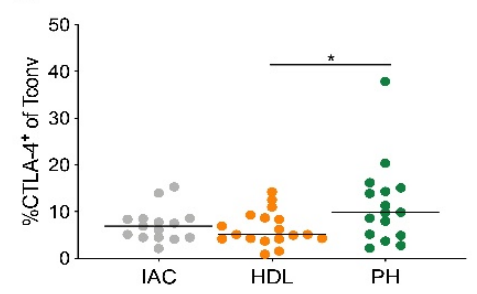

\section{D}

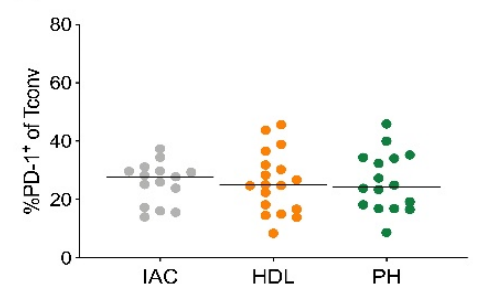

E

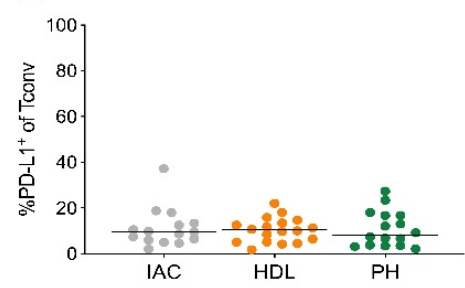

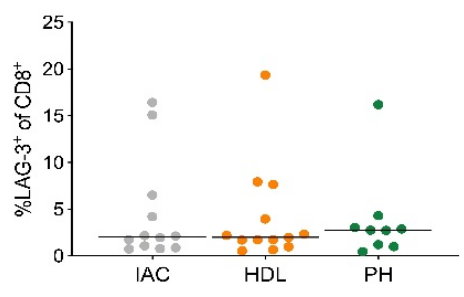
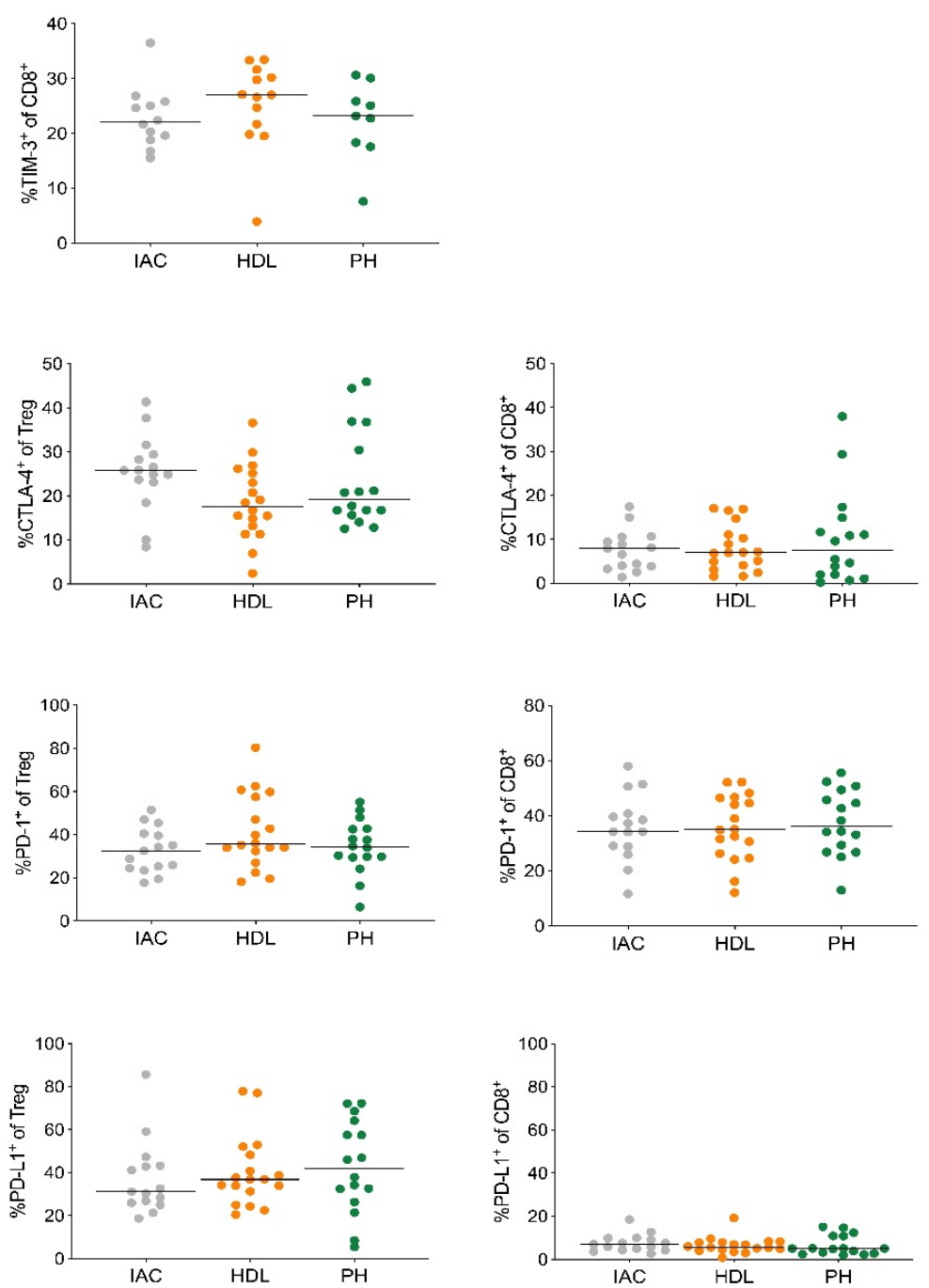

Figure 4. Treg cells in PDAC-draining lymph nodes express PD-1 and PD-L1. (A) Quantification of the expression of LAG-3 and (B) TIM-3 on CD4 ${ }^{+}$(left) and CD8 ${ }^{+}$T cells (right). (C) Quantification of the expression of CTLA-4, (D) PD-1 and (E) PD-L1 on CD4 ${ }^{+}$Tconv cells (Tconv; left), regulatory T cells (Treg; middle) and $\mathrm{CD}^{+} \mathrm{T}$ cells $\left(\mathrm{CD}^{+}\right.$; right). IAC, interaortocaval; HDL, hepatoduodenal ligament; $\mathrm{PH}$, pancreatic head. Each point represents data from one patient. Data, median. One-way ANOVA. * $p<0.05$. 


\subsection{PD-1-Expressing Lymph Node T Cells Are Associated with Node-Positive PDAC}

Next, we analyzed the relationship of inhibitory receptor expression in T cells with tumor stage. Despite no relevant association of PD-1 expression with tumor size (data not shown), patients with lymph node metastasis $(\mathrm{N}+)$ had significantly higher PD-1 expression on $\mathrm{CD}^{+}$Tconv, Treg cells and $\mathrm{CD}^{+} \mathrm{T}$ cells compared to patients without lymph node metastasis (N-; Figure 5A-C).

A
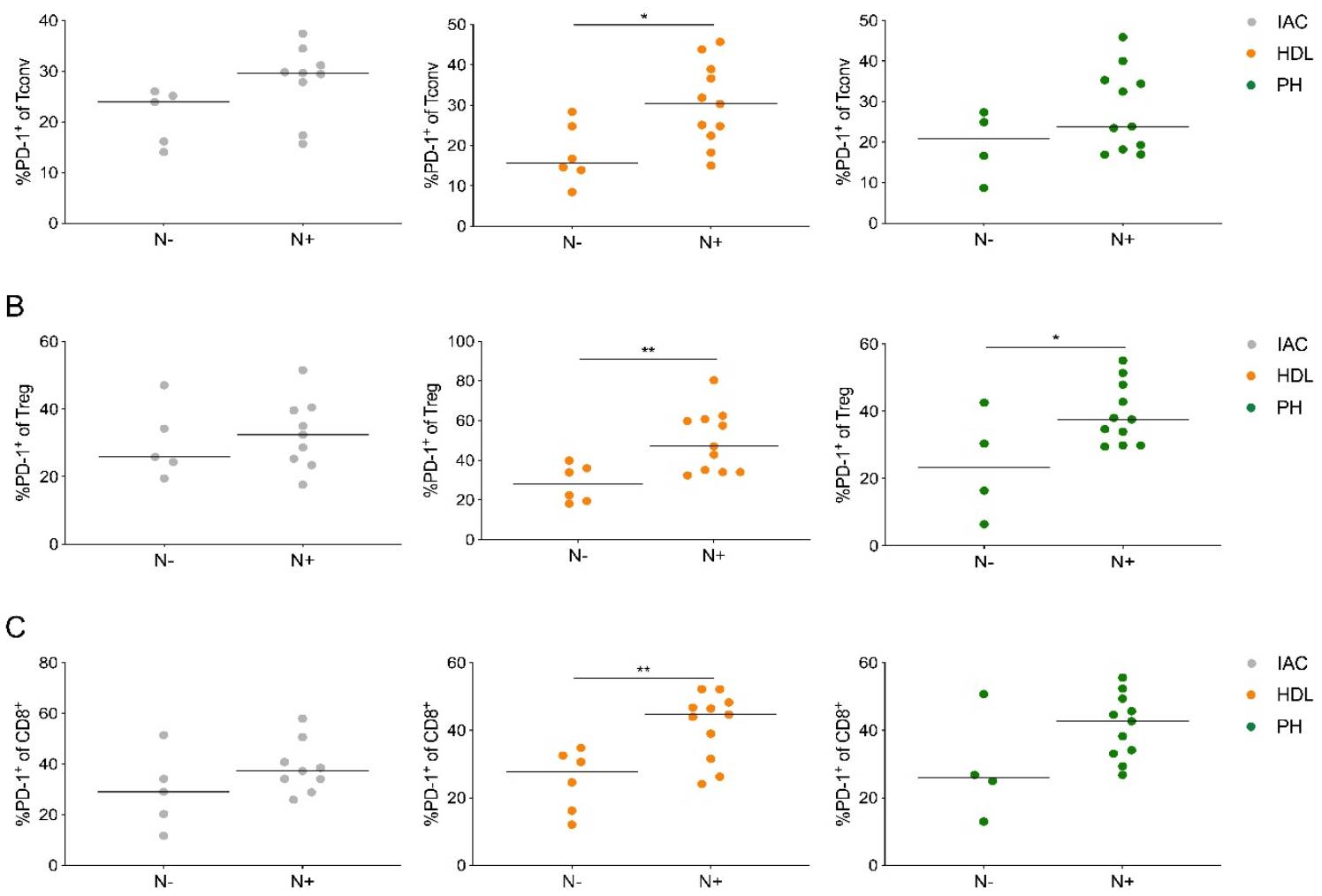

Figure 5. PD-1-expressing lymph node $\mathrm{T}$ cells are associated with node-positive PDAC. (A) Quantification of the expression of PD-1 on CD4 ${ }^{+}$Tconv cells (Tconv), (B) regulatory T cells (Treg) and $(C) \mathrm{CD}^{+} \mathrm{T}$ cells $\left(\mathrm{CD}^{+}\right)$based on nodal stage $(\mathrm{N}-$, negative; $\mathrm{N}+$, positive). IAC, interaortocaval; HDL, hepatoduodenal ligament; $\mathrm{PH}$, pancreatic head. Each point represents data from one patient. Data, median. Unpaired $t$-test. ${ }^{*} p<0.05,{ }^{* *} p \leq 0.01$.

Especially in the lymph node from the hepatoduodenal ligament PD-1, expression by all three T cell populations was associated with lymph node metastasis. Collectively, PD-1 expression by lymph node $\mathrm{T}$ cells correlates with nodal disease and may be involved in the metastatic process into regional lymph nodes in PDAC.

\subsection{PD-1 Expression by Intratumoral Treg Cells Correlates with Node-Positive PDAC}

To further elucidate the role of PD-1 expression by T cells in PDAC patients, we analyzed tumors and matched blood samples from a separate cohort of 16 PDAC patients (Table S2) and determined PD-1 expression using flow cytometry. Representative dot plots for $\mathrm{T}$ cell gating are shown (Figure 6A).

The frequency of Treg cells and CD8 $8^{+} \mathrm{T}$ cells was significantly increased in PDAC compared to matched blood samples (Figure 6B). Further, all intratumoral T cells displayed higher PD-1 expression compared to their circulating counterpart (Figure 6C). T cell frequencies were not associated with lymph node metastasis (data not shown), whereas PD-1 expression by intratumoral Treg cells correlated with node-positive PDAC (N+, Figure 6D). Thus, consistent with our previous observation from TDLNs, PD-1 expression by intratumoral Treg cells also correlated with lymph node metastasis. 
A
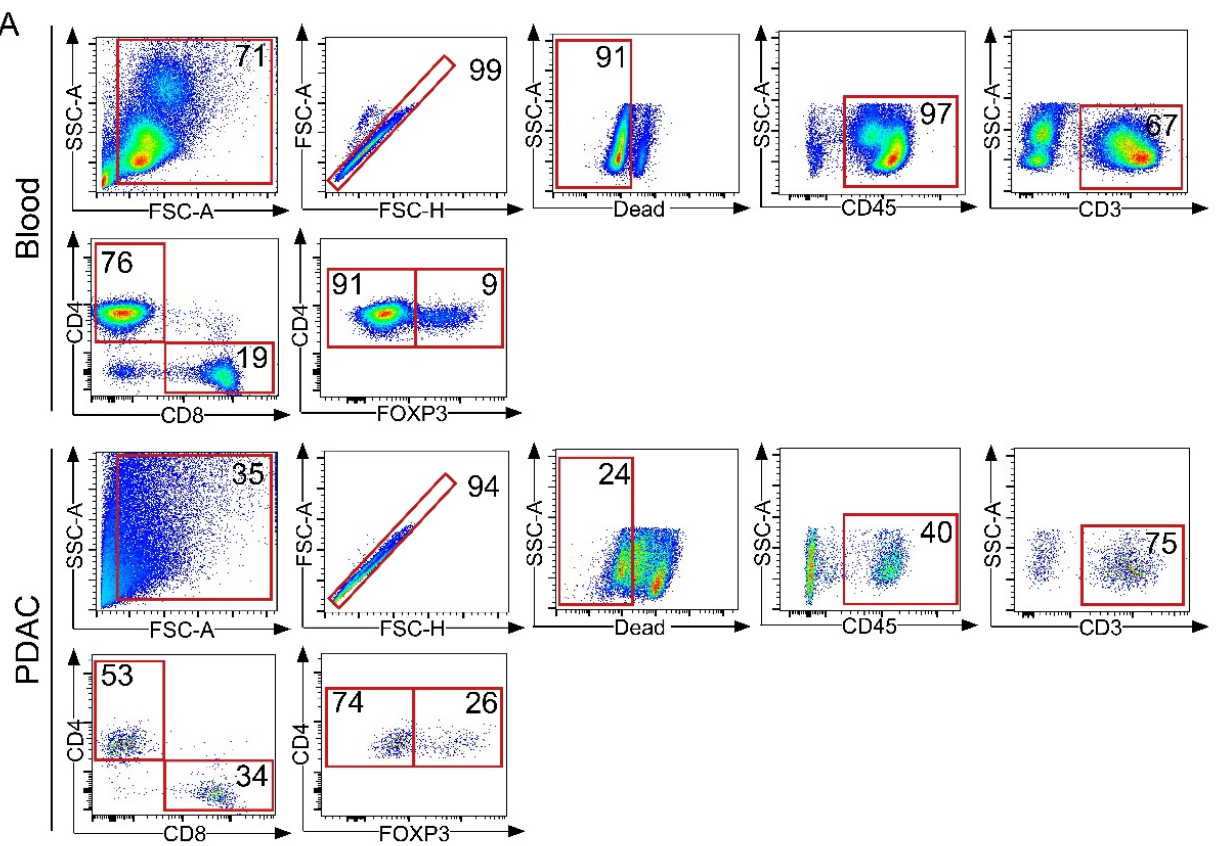

B

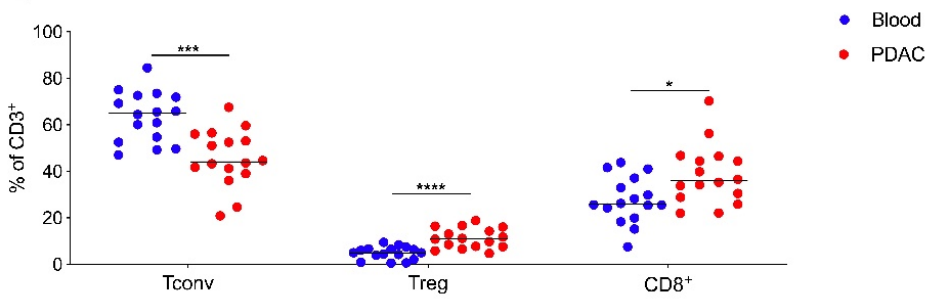

$\mathrm{C}$
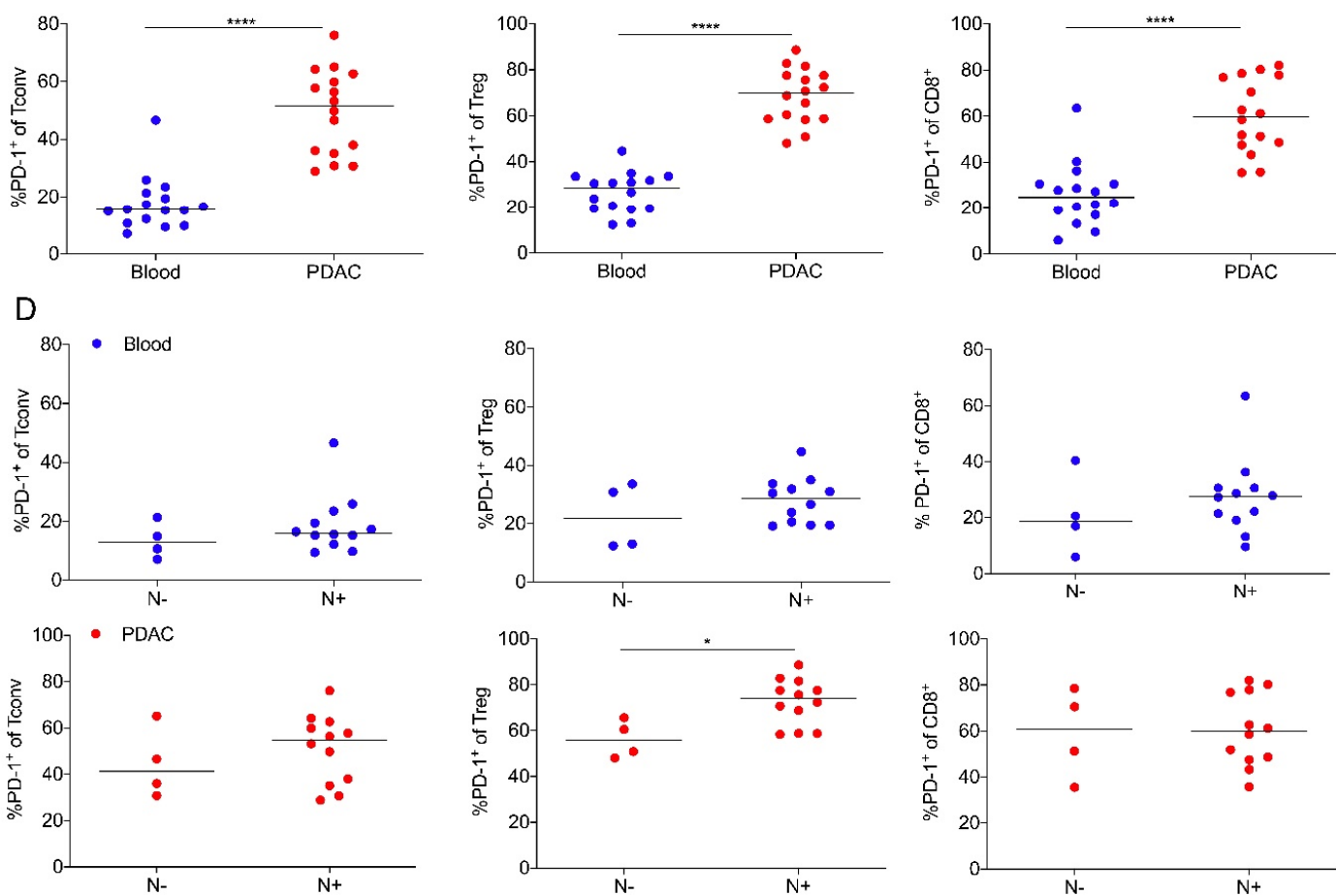

Figure 6. PD-1 expression by intratumoral Treg cells correlates with node-positive PDAC. (A) Representative flow cytometric gating strategy for the identification of T cells in blood (top) and PDAC (bottom). Number indicates percentage of population per gate. SSC, side scatter; FSC, forward scatter. 
(B) $\mathrm{CD}^{+}$Tconv cells (Tconv; $\mathrm{CD}^{+} \mathrm{CD}^{+}{ }^{+} \mathrm{CD}^{-} \mathrm{FOXP3}^{-}$), regulatory $\mathrm{T}$ cells (Treg; $\mathrm{CD}^{+} \mathrm{CD}^{+}{ }^{+} \mathrm{CD}^{-} \mathrm{FOXP3}^{+}$) and $\mathrm{CD}^{+} \mathrm{T}$ cells $\left(\mathrm{CD} 8^{+} ; \mathrm{CD}^{+}{ }^{+} \mathrm{CD} 4^{-} \mathrm{CD} 8^{+}\right)$as a percentage of $\mathrm{CD}^{+} \mathrm{T}$ cells in blood and tumor from 16 patients with PDAC. (C) Percentages of PD-1 expression of indicated T cell subset in blood and PDAC. (D) Quantification of the expression of PD-1 on blood (top) and tumor-infiltrating T cells (PDAC, bottom) based on nodal stage $(\mathrm{N}-$, negative; $\mathrm{N}+$, positive). Each point represents data from one patient. Data, median. Unpaired $t$-test. ${ }^{* * *} p \leq 0.0001,{ }^{* * *} p \leq 0.001,{ }^{*} p<0.05$.

\section{Discussion}

The 5-year survival for microscopically margin-negative (R0)-resected PDAC patients with lymph node metastasis ranges from 10 to $15 \%$, as opposed to $37 \%$ for patients without lymphatic tumor cell dissemination [2]. TDLNs are not only the preferential site of initial tumor metastasis, but also the primary site of tumor antigen presentation, immune activation and regulation. There is substantial evidence that immune modulation occurs not only in the tumor, but also in TDLNs, which may facilitate lymph node metastasis [22].

In this study, we analyzed $\mathrm{T}$ cells from different lymph node locations relative to the primary tumor in the pancreatic head. According to the probability of lymph node metastasis, we chose lymph nodes from the posterior aspect of the pancreatic head (pancreatic head, $\mathrm{PH}$ ), along the hepatic artery and bile duct (hepatoduodenal ligament, HDL) and around the abdominal aorta (interaortocaval, IAC) for analysis (54.3\%, $16.1 \%$, and $12.5 \%$, respectively) [3]. Notably, interaortocaval lymph node involvement is considered as distant metastasis and tumors are staged UICC IV accordingly [23].

Our comprehensive flow cytometric analysis indicated that T cells in PDAC-draining lymph nodes have a similar frequency, differentiation stage and phenotype independent of proximity to the tumor. However, we provide evidence for a relevant role of PD-1-expression for lymph node metastasis in PDAC. Our findings suggest that the presence of PD- $1^{+} \mathrm{T}$ cells either occurs before lymphatic tumor cell spread and potentially facilitates tumor cell infiltration, or that Treg cells in TDLNs upregulate PD-1 in response to their interaction with tumor cells. Generally, PD-1 expression has been demonstrated to identify $\mathrm{T}$ cells that recognize tumor-specific proteins $[24,25]$. Our data indicate a relevant role for PD-1 in the immune suppressive network of PDAC-draining lymph nodes.

Additionally, we observed that PD-1 expression by intratumoral Treg cells correlated with lymph node metastasis. Whether Treg cells contribute directly to conditioning of premetastatic niches warrants further investigation. Notably, in a recent study, intratumoral Treg cell density correlated with lymphatic metastasis [15]. PDAC cells express high levels of C-C chemokine ligand 5 (CCL5) to recruit Treg cells through C-C chemokine receptor 5 (CCR5) [26]. In cervical cancer patients, a PD-L1-expressing antigen-presenting cell (APC) subset in metastatic lymph nodes correlated with an increased frequency of Treg cells [27]. Colorectal cancer patients with lymph node metastasis had an increased frequency of Treg cells, which was associated with impaired $\mathrm{CD}^{+} \mathrm{T}$ cell function [28]. However, in our study, Treg cell frequency was not associated with lymph node metastasis. The frequency of $\mathrm{CD} 10^{+}$pancreatic stellate cells in PDAC correlated with nodal metastasis and shorter survival [29]. Additionally, IL-4-expressing basophils have been shown to be enriched in PDAC-draining lymph nodes and the percentage of basophils in the TDLNs was identified as an independent prognostic factor for worse survival after surgery [30]. The presence of PD-1+ Treg cells may be useful as a predictive marker for patient survival, but unlikely a stronger predictive factor than lymph node metastasis itself.

Multiple preclinical murine models show that Treg cells are important for the establishment of metastatic sites following dissemination of tumor cells [31]. For example, the receptor activator of nuclear factor kappa-B ligand (RANKL) on Treg cells directly promoted pulmonary metastasis in breast cancer [32]. In a murine PDAC model, Treg cells restrained the function of dendritic cells (DCs) by suppressing the expression of costimulatory ligands necessary for $\mathrm{CD} 8^{+} \mathrm{T}$ cell activation [33]. Further investigations into the mechanisms of Treg recruitment and their role at metastatic sites are warranted.

Further, neoadjuvant therapy was associated with a reduction of suppressive immune cells, including Treg cells and myeloid-derived suppressor cells (MDSCs) in PDAC [34]. Long-term treatment with gemcitabine has been shown to lead to extensive reprogramming of the pancreatic cancer 
microenvironment, sensitizing murine PDAC to immunotherapy [35]. In the setting of TGF $\beta$ signaling deficiency, gemcitabine and PD-1 blockade reduced tumor growth mediated through $\mathrm{CD} 8^{+} \mathrm{T}$ cells. Agonist anti-CD40 therapy with chemotherapy reversed the complete resistance of murine pancreatic tumors to PD-1 and CTLA-4 blockade [36]. Endogenous tumor-reactive T cells are present within the human PDAC tumor microenvironment and can be reactivated by combined blockade of PD-1 and C-X-C chemokine receptor 4 (CXCR4) [37]. These preclinical observations argue against the currently accepted paradigm that PDAC does not respond to immunotherapy due to a lack of immunogenicity or generation of tumor-reactive $\mathrm{T}$ cells.

\section{Materials and Methods}

\subsection{Patient Samples}

Blood, tumor and lymph node specimens were obtained from patients with PDAC, who underwent surgery at our institution. All patients consented to a protocol approved by the Ethics Committee of the TU Dresden (No EK446112017). Lymph nodes from the posterior aspect of the pancreatic head, along the hepatic artery and bile duct, and around the abdominal aorta were identified and divided [38]. One part was formalin-fixed, paraffin-embedded and a serial section was stained with $\mathrm{H} \& \mathrm{E}$ for histologic evaluation, while the remaining specimen was subjected to mechanical dissociation to obtain single-cell suspensions. Blood and tumors were processed as previously described [39]. Cells were analyzed with flow cytometry. Only lymph nodes with a sufficient cell number for each multicolor flow cytometry panel were used. The clinical stages of tumors were determined according to the tumor-node-metastasis (TNM) classification system by the Union for International Cancer Control (UICC; Edition 8). Patient characteristics are shown in Tables S1 and S2.

\subsection{Flow Cytometry and Antibodies}

Single-cell suspensions for flow cytometry were prepared and samples were stained with monoclonal antibodies directed against CD45 (HI30), CD3 (SK7 or UCHT1), CD4 (RPA-T4), CD8 (RUO), CD25 (M-A251), CD27 (M-T271), CD28 (CD28.2), CD45RA (H100), CD45RO (UCHL1), CD69 (L78), CD95 (DX2), CD107a (H4A3), CD127 (HIL-7R-M21), CD197 (3D12), CD274 (MIH1), CD19 (HIB19), FOXP3 (259D/C7), IFN- $\gamma$ (25723.11, all BD Biosciences), CD123 (6H6), CD152 (L3D10), CD279 (EH12.2H7), ICOS (C398.4A), TIM-3 (F38-2E2, all BioLegend; San Diego, USA), and LAG-3 (R\&D Systems; Minneapolis, USA) according to the manufacturer's protocol. FOXP3 was stained using the human FOXP3 Buffer Set (BD Biosciences; Franklin Lakes, USA) according to the manufacturer's protocol. For intracellular cytokine staining, cells were stimulated with phorbol 12-myristate 13-acetate (PMA, $50 \mathrm{ng} / \mathrm{mL}$ ) and ionomycin $\left(750 \mathrm{ng} / \mathrm{mL}\right.$ ) for 4 hours at $37^{\circ} \mathrm{C}, 5 \% \mathrm{CO} 2$ in the presence of $1 \mathrm{mg} / \mathrm{mL}$ brefeldin A (BD Biosciences; Franklin Lakes, USA). Surface staining was performed, and cells were fixed and permeabilized with the BD Cytofix/Cytoperm Kit and stained for CD107a and IFN- $\gamma$. Flow cytometry was carried out on the Aria flow cytometer (BD Biosciences; Franklin Lakes, USA). Data were analyzed using FlowLogic $700.2 \mathrm{a}$ (Inivai ${ }^{\mathrm{TM}}$ Technologies, Mentone, Australia).

\subsection{Statistical Analysis}

Data are shown as median \pm SEM. Unpaired Student's $t$-test or one-way ANOVA comparisons were performed as applicable. GraphPad Prism 8.0 (GraphPad Software, La Jolla, CA) was used. $p \leq 0.05$ was considered significant.

\section{Conclusions}

In this study, we broadly characterized the composition and phenotype of T cells within TDLNs in human PDAC. Our data identified PD-1 and Treg cells as relevant elements of the immunosuppressive network contributing to lymphatic tumor cell spread in human PDAC. Both components are potential immunotherapeutic targets for selected PDAC patients with lymph node metastasis. 
Supplementary Materials: The following are available online at http://www.mdpi.com/2072-6694/12/10/2756/s1, Table S1: Clinicopathologic characteristics of patients in the lymph node cohort, Table S2: Clinicopathologic characteristics of patients in the blood and tumor cohort.

Author Contributions: Conceptualization, A.M.S., C.R., M.S. and L.S.; data curation, A.E., M.H., R.W. and A.T.; formal analysis, A.M.S., A.E., M.H., R.W. and A.T.; funding acquisition, A.M.S. and L.S.; investigation, A.M.S., A.E., M.H., R.W. and A.T.; methodology, A.E., M.H., R.W. and A.T.; project administration, A.M.S., C.R., J.W., M.S and L.S.; resources, A.M.S., M.S. and L.S.; supervision, A.M.S. and L.S.; validation, A.M.S., D.E.A., M.S. and L.S.; visualization, A.M.S. and A.E.; writing - original draft preparation, A.M.S. and L.S.; writing - review and editing, A.E., M.H., R.W., A.T., J.v.R., R.D., D.A.E., T.W., C.R., J.W., M.S. and L.S. All authors have read and agreed to the published version of the manuscript.

Funding: This work was supported by the Ernst-Jung Stiftung, the Monika Kutzner Stiftung, the German Research Foundation (DFG; SE2980/5-1), the German Cancer Consortium (DKTK) and the Medical Faculty Carl Gustav Carus TU Dresden.

Conflicts of Interest: The authors declare no conflict of interest.

\section{References}

1. Siegel, R.L.; Miller, K.D.; Jemal, A. Cancer statistics, 2020. CA Cancer J. Clin. 2020, 70, 7-30. [CrossRef]

2. Allen, P.J.; Kuk, D.; Castillo, C.F.-D.; Basturk, O.; Wolfgang, C.L.; Cameron, J.L.; Lillemoe, K.D.; Ferrone, C.R.; Morales-Oyarvide, V.; He, J.; et al. Multi-institutional Validation Study of the American Joint Commission on Cancer (8th Edition) Changes for T and N Staging in Patients with Pancreatic Adenocarcinoma. Ann. Surg. 2017, 265, 185-191. [CrossRef]

3. Kanda, M.; Fujii, T.; Nagai, S.; Kodera, Y.; Kanzaki, A.; Sahin, T.T.; Hayashi, M.; Yamada, S.; Sugimoto, H.; Nomoto, S.; et al. Pattern of Lymph Node Metastasis Spread in Pancreatic Cancer. Pancreas 2011, 40, 951-955. [CrossRef]

4. Royal, R.E.; Levy, C.; Turner, K.; Mathur, A.; Hughes, M.; Kammula, U.S.; Sherry, R.M.; Topalian, S.L.; Yang, J.C.; Lowy, I.; et al. Phase 2 Trial of Single Agent Ipilimumab (Anti-CTLA-4) for Locally Advanced or Metastatic Pancreatic Adenocarcinoma. J. Immunother. 2010, 33, 828-833. [CrossRef] [PubMed]

5. Brahmer, J.R.; Tykodi, S.S.; Chow, L.Q.; Hwu, W.-J.; Topalian, S.L.; Hwu, P.; Drake, C.G.; Camacho, L.H.; Kauh, J.; Odunsi, K.; et al. Safety and Activity of Anti-PD-L1 Antibody in Patients with Advanced Cancer. N. Engl. J. Med. 2012, 366, 2455-2465. [CrossRef] [PubMed]

6. Patnaik, A.; Kang, S.P.; Rasco, D.; Papadopoulos, K.P.; Elassaiss-Schaap, J.; Beeram, M.; Drengler, R.; Chen, C.; Smith, L.; Espino, G.; et al. Phase I Study of Pembrolizumab (MK-3475; Anti-PD-1 Monoclonal Antibody) in Patients with Advanced Solid Tumors. Clin. Cancer Res. 2015, 21, 4286-4293. [CrossRef] [PubMed]

7. Fransen, M.F.; Schoonderwoerd, M.; Knopf, P.; Camps, M.G.; Hawinkels, L.J.; Kneilling, M.; van Hall, T.; Ossendorp, F. Tumor-draining lymph nodes are pivotal in PD-1/PD-L1 checkpoint therapy. JCI Insight 2018, 3, e124507. [CrossRef] [PubMed]

8. Balli, D.; Rech, A.J.; Stanger, B.Z.; Vonderheide, R.H. Immune Cytolytic Activity Stratifies Molecular Subsets of Human Pancreatic Cancer. Clin. Cancer Res. 2016, 23, 3129-3138. [CrossRef] [PubMed]

9. Shibuya, K.C.; Goel, V.K.; Xiong, W.; Sham, J.G.; Pollack, S.M.; Leahy, A.M.; Whiting, S.H.; Yeh, M.M.; Yee, C.; Riddell, S.R.; et al. Pancreatic Ductal Adenocarcinoma Contains an Effector and Regulatory Immune Cell Infiltrate that Is Altered by Multimodal Neoadjuvant Treatment. PLoS ONE 2014, 9, e96565. [CrossRef]

10. Daley, D.; Zambirinis, C.P.; Seifert, L.; Akkad, N.; Mohan, N.; Werba, G.; Barilla, R.; Torres-Hernandez, A.; Hundeyin, M.; Raj, V.; et al. $\gamma \delta$ T Cells Support Pancreatic Oncogenesis by Restraining $\alpha \beta$ T Cell Activation. Cell 2016, 166, 1485-1499.e15. [CrossRef]

11. Poschke, I.; Faryna, M.; Bergmann, F.; Flossdorf, M.; Lauenstein, C.; Hermes, J.; Hinz, U.; Hank, T.; Ehrenberg, R.; Volkmar, M.; et al. Identification of a tumor-reactive T-cell repertoire in the immune infiltrate of patients with resectable pancreatic ductal adenocarcinoma. Oncoimmunology 2016, 5, e1240859. [CrossRef] [PubMed]

12. Stromnes, I.M.; Hulbert, A.; Pierce, R.H.; Greenberg, P.D.; Hingorani, S.R. T-cell Localization, Activation, and Clonal Expansion in Human Pancreatic Ductal Adenocarcinoma. Cancer Immunol. Res. 2017, 5, $978-991$. [CrossRef] 
13. Carstens, J.L.; De Sampaio, P.C.; Yang, D.; Barua, S.; Wang, H.; Rao, A.; Allison, J.; LeBleu, V.S.; Kalluri, R. Spatial computation of intratumoral $\mathrm{T}$ cells correlates with survival of patients with pancreatic cancer. Nat. Commun. 2017, 8, 15095. [CrossRef] [PubMed]

14. Tang, Y.; Xu, X.; Guo, S.; Zhang, C.; Tang, Y.; Tian, Y.; Ni, B.; Lu, B.; Wang, H. An Increased Abundance of Tumor-Infiltrating Regulatory T Cells Is Correlated with the Progression and Prognosis of Pancreatic Ductal Adenocarcinoma. PLoS ONE 2014, 9, e91551. [CrossRef] [PubMed]

15. Jiang, Y.; Du, Z.; Yang, F.; Di, Y.; Li, J.; Zhou, Z.; Pillarisetty, V.G.; Fu, D. FOXP3+ Lymphocyte Density in Pancreatic Cancer Correlates with Lymph Node Metastasis. PLoS ONE 2014, 9, e106741. [CrossRef] [PubMed]

16. Liyanage, U.K.; Moore, T.T.; Joo, H.-G.; Tanaka, Y.; Herrmann, V.; Doherty, G.M.; Drebin, J.A.; Strasberg, S.M.; Eberlein, T.J.; Goedegebuure, P.S.; et al. Prevalence of regulatory T cells is increased in peripheral blood and tumor microenvironment of patients with pancreas or breast adenocarcinoma. J. Immunol. 2002, 169, 2756-2761. [CrossRef] [PubMed]

17. Soares, K.C.; Rucki, A.A.; Wu, A.A.; Olino, K.; Xiao, Q.; Chai, Y.; Wamwea, A.; Bigelow, E.; Lutz, E.; Liu, L.; et al. PD-1/PD-L1 blockade together with vaccine therapy facilitates effector T-cell infiltration into pancreatic tumors. J. Immunother. 2015, 38, 1-11. [CrossRef] [PubMed]

18. Nomi, T.; Sho, M.; Akahori, T.; Hamada, K.; Kubo, A.; Kanehiro, H.; Nakamura, S.; Enomoto, K.; Yagita, H.; Azuma, M.; et al. Clinical Significance and Therapeutic Potential of the Programmed Death-1 Ligand/Programmed Death-1 Pathway in Human Pancreatic Cancer. Clin. Cancer Res. 2007, 13, 2151-2157. [CrossRef] [PubMed]

19. Mahnke, Y.D.; Brodie, T.M.; Sallusto, F.; Roederer, M.; Lugli, E. The who's who of T-cell differentiation: Human memory T-cell subsets. Eur. J. Immunol. 2013, 43, 2797-2809. [CrossRef] [PubMed]

20. Anderson, A.C.; Joller, N.; Kuchroo, V.K. Lag-3, Tim-3, and TIGIT: Co-inhibitory Receptors with Specialized Functions in Immune Regulation. Immunity 2016, 44, 989-1004. [CrossRef]

21. Baitsch, L.; Baumgaertner, P.; Devevre, E.; Raghav, S.K.; Legat, A.; Barba, L.; Wieckowski, S.; Bouzourene, H.; Deplancke, B.; Romero, P.; et al. Exhaustion of tumor-specific $\mathrm{CD}^{+} \mathrm{T}$ cells in metastases from melanoma patients. J. Clin. Investig. 2011, 121, 2350-2360. [CrossRef]

22. Shu, S.; Cochran, A.J.; Huang, R.-R.; Morton, D.L.; Maecker, H.T. Immune responses in the draining lymph nodes against cancer: Implications for immunotherapy. Cancer Metastasis Rev. 2006, 25, 233-242. [CrossRef] [PubMed]

23. Sho, M.; Murakami, Y.; Motoi, F.; Satoi, S.; Matsumoto, I.; Kawai, M.; Honda, G.; Uemura, K.; Yanagimoto, H.; Kurata, M.; et al. Postoperative prognosis of pancreatic cancer with para-aortic lymph node metastasis: A multicenter study on 822 patients. J. Gastroenterol. 2014, 50, 694-702. [CrossRef] [PubMed]

24. Gros, A.; Robbins, P.F.; Yao, X.; Li, Y.F.; Turcotte, S.; Tran, E.; Wunderlich, J.R.; Mixon, A.; Farid, S.; Dudley, M.E.; et al. PD-1 identifies the patient-specific $\mathrm{CD}^{+}$tumor-reactive repertoire infiltrating human tumors. J. Clin. Investig. 2014, 124, 2246-2259. [CrossRef] [PubMed]

25. Gros, A.; Tran, E.; Parkhurst, M.R.; Ilyas, S.; Pasetto, A.; Groh, E.M.; Robbins, P.F.; Yossef, R.; Garcia-Garijo, A.; Fajardo, C.A.; et al. Recognition of human gastrointestinal cancer neoantigens by circulating PD-1+ lymphocytes. J. Clin. Investig. 2019, 129, 4992-5004. [CrossRef] [PubMed]

26. Tan, M.C.B.; Goedegebuure, P.S.; Belt, B.A.; Flaherty, B.; Sankpal, N.; Gillanders, W.E.; Eberlein, T.J.; Hsieh, C.-S.; Linehan, D.C. Disruption of CCR5-dependent homing of regulatory T cells inhibits tumor growth in a murine model of pancreatic cancer. J. Immunol. 2009, 182, 1746-1755. [CrossRef] [PubMed]

27. Heeren, A.M.; Koster, B.D.; Samuels, S.; Ferns, D.M.; Chondronasiou, D.; Kenter, G.G.; Jordanova, E.S.; De Gruijl, T.D. High and Interrelated Rates of PD-L1+CD14+ Antigen-Presenting Cells and Regulatory T Cells Mark the Microenvironment of Metastatic Lymph Nodes from Patients with Cervical Cancer. Cancer Immunol. Res. 2014, 3, 48-58. [CrossRef]

28. Deng, L.; Zhang, H.; Luan, Y.; Zhang, J.; Xing, Q.; Dong, S.; Wu, X.; Liu, M.; Wang, S. Accumulation of Foxp3+ T Regulatory Cells in Draining Lymph Nodes Correlates with Disease Progression and Immune Suppression in Colorectal Cancer Patients. Clin. Cancer Res. 2010, 16, 4105-4112. [CrossRef]

29. Ikenaga, N.; Ohuchida, K.; Mizumoto, K.; Cui, L.; Kayashima, T.; Morimatsu, K.; Moriyama, T.; Nakata, K.; Fujita, H.; Tanaka, M. CD10+ Pancreatic Stellate Cells Enhance the Progression of Pancreatic Cancer. Gastroenterology 2010, 139, 1041-1051.e8. [CrossRef] 
30. De Monte, L.; Woermann, S.; Brunetto, E.; Heltai, S.; Magliacane, G.; Reni, M.; Paganoni, A.M.; Recalde, H.; Mondino, A.; Falconi, M.; et al. Basophil Recruitment into Tumor-Draining Lymph Nodes Correlates with Th2 Inflammation and Reduced Survival in Pancreatic Cancer Patients. Cancer Res. 2016, 76, 1792-1803. [CrossRef]

31. Halvorsen, E.C.; Mahmoud, S.M.; Bennewith, K.L. Emerging roles of regulatory T cells in tumour progression and metastasis. Cancer Metastasis Rev. 2014, 33, 1025-1041. [CrossRef] [PubMed]

32. Tan, W.; Zhang, W.; Strasner, A.; Grivennikov, S.; Cheng, J.Q.; Hoffman, R.M.; Karin, M. Tumour-infiltrating regulatory $\mathrm{T}$ cells stimulate mammary cancer metastasis through RANKL-RANK signalling. Nature 2011, 470, 548-553. [CrossRef] [PubMed]

33. Jang, J.-E.; Hajdu, C.H.; Liot, C.; Miller, G.; Dustin, M.L.; Bar-Sagi, D. Crosstalk between Regulatory T Cells and Tumor-Associated Dendritic Cells Negates Anti-tumor Immunity in Pancreatic Cancer. Cell Rep. 2017, 20, 558-571. [CrossRef] [PubMed]

34. Reyes, C.M.; Teller, S.; Muckenhuber, A.; Konukiewitz, B.; Safak, O.; Weichert, W.; Friess, H.; Ceyhan, G.O.; Demir, I.E. Neoadjuvant Therapy Remodels the Pancreatic Cancer Microenvironment via Depletion of Protumorigenic Immune Cells. Clin. Cancer Res. 2019, 26, 220-231. [CrossRef] [PubMed]

35. Principe, D.R.; Narbutis, M.; Kumar, S.; Park, A.; Viswakarma, N.; Dorman, M.J.; Kamath, S.D.; Grippo, P.J.; Fishel, M.L.; Hwang, R.F.; et al. Long-Term Gemcitabine Treatment Reshapes the Pancreatic Tumor Microenvironment and Sensitizes Murine Carcinoma to Combination Immunotherapy. Cancer Res. 2020, 80, 3101-3115. [CrossRef] [PubMed]

36. Winograd, R.; Byrne, K.T.; Evans, R.A.; Odorizzi, P.M.; Meyer, A.R.L.; Bajor, D.L.; Clendenin, C.; Stanger, B.Z.; Furth, E.E.; Wherry, E.J.; et al. Induction of T-cell Immunity Overcomes Complete Resistance to PD-1 and CTLA-4 Blockade and Improves Survival in Pancreatic Carcinoma. Cancer Immunol. Res. 2015, 3, $399-411$. [CrossRef] [PubMed]

37. Seo, Y.D.; Jiang, X.; Sullivan, K.M.; Jalikis, F.G.; Smythe, K.S.; Abbasi, A.; Vignali, M.; Park, J.O.; Daniel, S.K.; Pollack, S.M.; et al. Mobilization of CD8+ T Cells via CXCR4 Blockade Facilitates PD-1 Checkpoint Therapy in Human Pancreatic Cancer. Clin. Cancer Res. 2019, 25, 3934-3945. [CrossRef] [PubMed]

38. Isaji, S.; Murata, Y.; Kishiwada, M. New Japanese Classification of Pancreatic Cancer. In Pancreatic Cancer; Neoptolemos, J., Urrutia, R., Abbruzzese, J., Büchler, M., Eds.; Springer: New York, NY, USA, 2018; pp. 1021-1037.

39. Seifert, A.M.; Reiche, C.; Heiduk, M.; Tannert, A.; Meinecke, A.-C.; Baier, S.; Von Renesse, J.; Kahlert, C.; Distler, M.; Welsch, T.; et al. Detection of pancreatic ductal adenocarcinoma with galectin-9 serum levels. Oncogene 2020, 39, 3102-3113. [CrossRef] [PubMed] 